\title{
The History of Religions School Today
}

\author{
Essays on the New Testament and Related Ancient Mediterranean Texts \\ Ed. by Thomas R. Blanton IV, Robert Matthew Calhoun and Clare K. Rothschild
}

[Die Religionsgeschichtliche Schule heute. Aufsätze zum Neuen Testament und zugehörigen antiken Schriften aus dem Mittelmeerraum.]

The History of Religions School Today

Edited by THOMAS R. BLANTON IV ROBERT MATTHEW CALHOUN and CLARE K. ROTHSCHILD

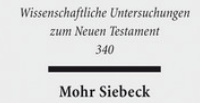

2014. XIII, 374 Seiten. WUNT I 340

ISBN 978-3-16-153437-9

DOI 10.1628/978-3-16-153437-9

eBook PDF 144,00 €

ISBN 978-3-16-153436-2

Leinen 144,00
Veröffentlicht auf Englisch.

Der vorliegende Band bietet Einblicke in die derzeit wieder populären Ansätze der angesehenen Religionsgeschichtlichen Schule zum Neuen Testament und der frühchristlichen Literatur. Sie entstand etwa im Jahre 1884 an der Universität Göttingen und wurde von Wissenschaftlern wie Albert Eichhorn, Wilhelm Bousset, Johannes Weiß und William Wrede vorangetrieben; die heutige Verwendung dieses Ansatzes ist vielfältig. Es ist unbestritten, dass die Universität von Chicago seit langem das Zentrum dieses Forschungsansatzes in Nordamerika ist. Im Laufe des letzten Jahrhunderts haben eine Vielzahl von Studien aus Chicago durch dieses Verfahren bahnbrechende Ergebnisse erzielt. In dieser Sammlung von Aufsätzen wenden Mitglieder der Chicagoer Schule den Ansatz auf verschiedene Themen an, um seinen bis heute fortdauernden Wert zu demonstrieren.

Inhaltsübersicht

I. Clare K. Rothschild: Introduction

II. New Testament

Paul

Mark Reasoner: Paul's God of Peace in Canonical and Political Perspectives - Robert Matthew Calhoun: Romans 1:18-32 among Ancient Accounts of the Origin of Religion - Meira Z. Kensky: The Hymnic Conclusion to Romans 11

Deutero-Pauline Literature

Jeff Asher: Missiles, Demagogues, and the Devil: The Rhetoric of Slander in Ephesians 6:16

Gospels/Acts

Laurie Brink, O.P.: Going the Extra Mile: Reading Matt 5:41 Literally and Metaphorically - David G. Monaco, C.P. : The Rhetoric of Narrative in Acts 8:26-40: Ramifications of the Baptism of the Ethiopian Eunuch for the Author of Luke-Acts

Apocalypse

Paul B. Duff: The Scroll, the Temple, and the Great City: The Crisis in the Asian Assemblies and the Interlude of Rev 10:1-11:13

Jewish Christianity

Matt Jackson-McCabe: Orthodoxy, Heresy, and Jewish Christianity: Reflections on Categories in Edwin Broadhead's Jewish Ways of Following Jesus - Jeffrey A. Trumbower: Christians, Sabbateans, and the Dead Sea Sect: A Comparative Case Study in Jewish Sectarian Logic

III. Related Ancient Mediterranean Texts

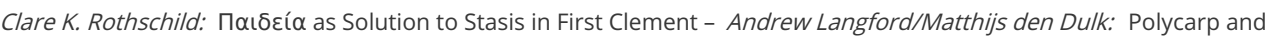
Polemo: Christianity at the Center of the Second Sophistic - Annette Bourland Huizenga: On Choosing a Wet-Nurse: Physical, Cultural and Moral Credentials - Justin Howell: Lucian's Hermotimus: A Fictive Dialogue with Marcus Aurelius - Thomas R. Blanton IV: De caelo patrocinium: The Economy of Divine Patronage in Apuleius' Metamorphoses Abstract

Clare K. Rothschild Born 1964; 1986 BA University of California, Berkeley; 1992 MTS Harvard University; 2003 PhD University of Chicago; 2006 postdoctoral fellow Alexander von Humboldt Foundation at Ludwig-Maximilians-Universität München; currently Professor of Scripture, Department of Theology, Lewis University (USA) and Professor Extraordinary, Department Ancient Studies at Stellenbosch University (South Africa).

https://orcid.org/0000-0002-6572-8604

Thomas R. Blanton IV Born 1968; 1991 BA (Psychology) University of North Carolina at Chapel Hill; 1994 M.T.S. Duke Divinity School; 2006 PhD (Biblical Studies) Divinity School, University of Chicago; Adjunct Professor of New Testament at Lutheran School of Theology at Chicago.

Robert Matthew Calhoun Born 1971; 2011 PhD in New Testament and Early Christian Literature from the University of Chicago; since 2016 Research Assistant to the A. A. Bradford Chair, Texas Christian University (USA). https://orcid.org/0000-0001-5056-2050

Jetzt bestellen:

https://mohrsiebeck.com/buch/the-history-of-religions-school-today-9783161534379?no_cache=1

order@mohrsiebeck.com

Telefon: +49 (0)7071-923-17 
Telefax: +49 (0)7071-51104

Mohr Siebeck GmbH \& Co. KG

Postfach 2040

D-72010 Tübingen

info@mohrsiebeck.com

Mohr Siebeck

www.mohrsiebeck.com 